\title{
Learning Effectiveness Using Different Teaching Modalities
}

Norman Carrol, Dominican University, USA

Molly Burke, Dominican University, USA

\begin{abstract}
There is much discussion about whether online instruction is as effective as face-to-face instruction. To address this question, a comparative study was made of two sections of an MBA organizational theory course, one taught online and the other face-to-face. The content covered by both sections was the same with similar assignments and a common final examination. There was little difference between the sections on the results of the final examination or the student course evaluations. This study suggests that neither modality is more effective than the other with regard to student achievement or their perceptions of course effectiveness.
\end{abstract}

Keywords: MBA; online learning; face-to-face learning; course evaluations; learning outcomes

\section{INTRODUCTION}

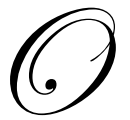

nline education has been the fastest growing segment of higher education. Because it is so unlike traditional classroom-based instruction, many questions have been raised as to the quality of the education offered in the online modality. After an extensive survey of the literature, the U.S. Department of Education issued a report concluding that the online or hybrid modalities are more effective than face-to-face instruction (U.S., n.d). Still, throughout the higher education community, many have reservations about the quality of online education. Educators question whether the content of courses is altered and if student learning is diminished as classes are delivered through these different conduits of instruction (Figure1).

To examine this question, a study was completed at a university school of business to ascertain which of two instructional modalities - online or face-to-face - was more effective. A comparison was made of two sections of a graduate organizational theory course required for the MBA degree, one taught face-to-face and the other online. The purpose was to investigate whether the conclusion of the Department of Education was valid. Students from both sections also completed a course evaluation report that provided subjective data on the effectiveness of the teaching modalities.

\section{REVIEW OF LITERATURE}

There is extensive literature comparing the strengths and weaknesses of online teaching versus face-to-face teaching. However, none of them address the opinion of students regarding the two modalities. Brownstein and Gerlowski (2008) compared the different modalities using an assessment rubric for two student essays. They found that learning outcomes were equally robust in either format. Gibson (2008) compared test scores from online and face-to-face sections of a course taught by the same instructor and found that the face-to-face students did slightly better than the online students. Chen and Jones (2007) examined two sections of a course, one taught face-to-face and the other taught primarily online and found that both courses had similar final learning outcomes.

Haavind (2000) concluded from his research that it was more difficult to monitor discussion in an online environment than in a classroom setting. Wong and Tatnall (2009) found that the ability to track the progress of students with an online learning management system increased the instructor's ability to assess students' progress in a way that is not possible in a traditional course. 
Figure 1: Different Modalities of Instruction

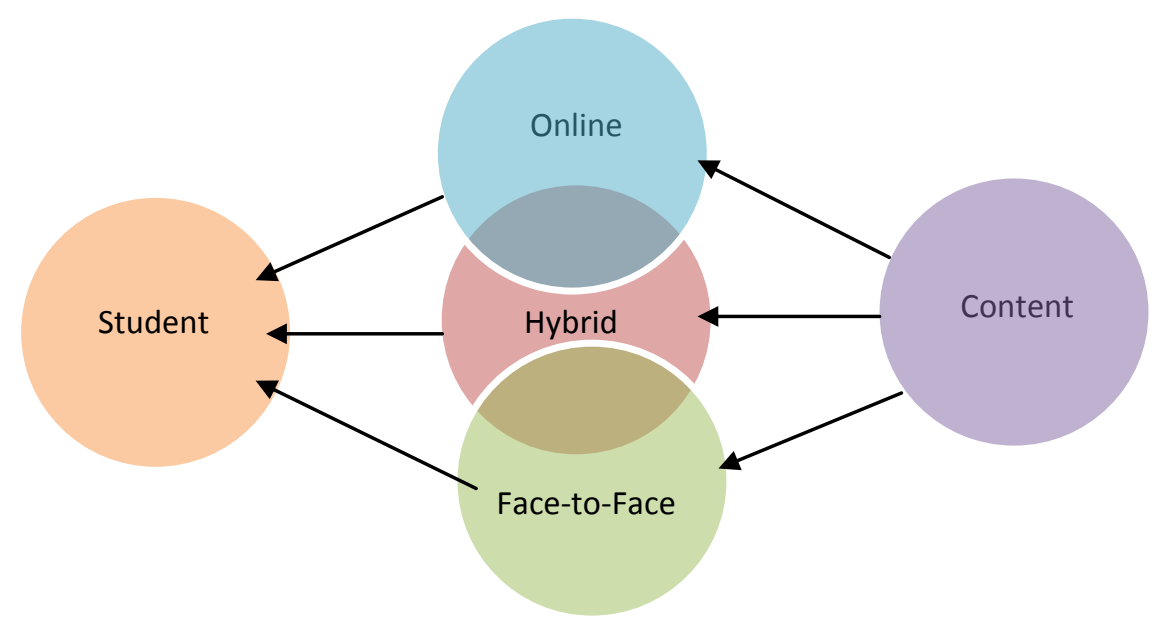

Several of the fundamental differences between learning online and in a traditional classroom setting were identified by McGovern (2004). These included the following: online learning requires students to have a certain level of computer skills and equipment that may not be necessary in the traditional environment; online instruction does not permit students the opportunity to learn by hearing since audio presentations are not normally available in online courses; and that online courses permit asynchronous learning rather than requiring students to be in a classroom at a given time and place.

In a survey of online faculty who had also taught face-to-face classes, it was found that one of the main differences in the instructional methods was that the online courses depend so much on texts (Teaching (2010). It was pointed out, however, that online courses are also able to bring in much more information from virtual sources and these can be more seamlessly integrated than in a face-to-face course. Those faculty who were surveyed indicated that one of the main advantages of an online course was the fact students needed to write everything and this is seen as allowing for a deeper understanding of the material.

Sipes and Ricciardi, (2006) also examined the nature of online and face-to-face education and concluded that the main difference is that online instruction is student centered while traditional courses are instructor centered. Sugar, Martindale and Crawley investigated the difficulty of transitioning from one mode to the other (2007). Turball (2002) described his experience in translating his face-to-face course to the online environment. He points out that the process changes the instructor's role to that of a facilitator and creates a challenge to keep the learning active.

One study surveyed an extensive list of students, from both domestic and foreign colleges and universities, who took classes in both mediums. The survey found that $48 \%$ of the students preferred the face-to-face medium and only 34\% preferred online classes (Kishore, et al, 2009). Another study found that there was no difference in the teaching functions of an instructor presenting the same material in the two different media (Alonso and Blazquez, 2009). Kirtman (2009), researching the difference between online and face-to-face instruction, found a significant difference in favor of the face-to-face students on the same midterm but no significant difference on the same final examination.

Larson and Sung (2009) researched a course that utilized the same instructor teaching sections in face-toface, online and in a hybrid modes and found no significant difference in the learning outcomes as measured in a 
common midterm and final. A study of the impact of the modality of instruction on student evaluation of instructors found that there was generally no significant difference in evaluations in terms of the format of instruction except in the case of minority instructors. Minority instructors received lower evaluations in a face-to-face medium than in an online one (Carle, 2009).

Singh and Stoloff (2007) surveyed a class and found that students believed they learned as much in an online course as they did in a face-to-face class. Cragg, Dunning and Ellis (2008) found in their study of a course taught in two different modalities, that there was no difference in the outcomes. Tutty and Kleine (2008) found that facilitating both online and face-to-face collaboration can lead to the development of effective learning strategies.

\section{OBJECTIVE OF STUDY}

The objective of this study is to verify the findings of the Department of Education study, which concluded that online and hybrid courses are more effective instructional modalities than face-to-face courses.

\section{HYPOTHESIS}

This research tests the hypotheses that online instruction leads to higher levels of student achievement than face-to-face instruction and would be evaluated by students as a more effective educational format.

\section{DATA COLLECTION}

To test the hypothesis, two sections of a graduate course in organizational theory were examined. One was conducted online and the other was taught using the traditional face-to-face method. The sections were taught by two different instructors, but the syllabi were similar. In Table 1, the elements of the course are compared between the two sections.

Table 1: Comparison of Syllabi

\begin{tabular}{|l|l|l|l|c|}
\hline & \multicolumn{3}{|c|}{ Syllabi Assignments and Weights } & \multicolumn{1}{c|}{ Online } \\
\hline & \multicolumn{1}{|c|}{ Face-to-Face } & Weight & Weight \\
\hline Textbook & R. Daft 10th Ed & & R. Daft 10th Ed & \\
\hline Discussion & In Class & & Online & \\
\hline $\begin{array}{l}\text { Current Journal } \\
\text { Analyses }\end{array}$ & $\begin{array}{l}\text { 2 reports } \\
3-4 \text { pages each }\end{array}$ & $10 \%$ & None & \\
\hline Term Paper & $5-8$ pages & $20 \%$ & $10-12$ Pages & $20 \%$ \\
\hline & $\begin{array}{l}11 \text { Cases Individually; } \\
1 \text { with Team } \\
\text { 5 page report }\end{array}$ & $20 \%$ & $\begin{array}{l}\text { 8 Cases Individually } \\
2 \text { page report }\end{array}$ & \\
Cases & Occasional & $10 \%$ & Weekly & $20 \%$ \\
\hline Quizzes & Written & $20 \%$ & None & $20 \%$ \\
\hline Final & Same & $20 \%$ & Same & $20 \%$ \\
\hline
\end{tabular}

Because the online section was taught over eight weeks, there was no midterm examination but both sections took the same final examination administered in a proctored setting. Since the objective of the study was to determine which one of the two instructional modalities produced more effective learning, student performance on the common final examination was used as the measure of learning. The results of this final examination were compared for the relative effectiveness of the two modalities.

Both sections were also given a course evaluation form to complete - the Student Instructional Report II (SIR II) - that was created and processed by the Educational Testing Service. This provided a subjective evaluation of the outcomes of each section of the course. In that evaluation, students reported on how they viewed the course outcomes including whether their learning increased as well as how much effort they made and how involved they were in the course (Appendix 1). 


\section{FINDINGS}

\section{Final Examination Results}

The results of the final examination are shown in Table 2. The number of wrong answers was calculated for each student and also totaled for the section. Summary statistics were then calculated for each section. A t-test was applied to the comparative means to check the statistical significance of the results. The null hypothesis was accepted which substantiated the fact that there was no significant difference between the online learning outcome and the face-to-face outcome.

Table 2: Comparison of Final Examinations

\begin{tabular}{|l|c|c|c|c|}
\hline & \multicolumn{3}{|c|}{ Final Exam Statistics } & \\
\hline \multicolumn{1}{|c|}{ Section } & N & Mean & Median & Std \\
\hline Online & 25 & 7.28 & 8.0 & 4.8 \\
\hline Face-to-Face & 27 & 7.04 & 7.0 & 2.7 \\
\hline
\end{tabular}

$\mathrm{t}=0.2244 \quad$ p .95 (Not significantly different)

\section{Student Evaluations}

From a student perspective, an analysis of the student course evaluations further supports the null hypothesis of this research. The students responded to evaluation items that were grouped into nine outcome areas (Table 3). The items were rated on a five-point scale with various meanings for each point on the scale. The highest rating, or most positive response, was a five. There was a choice for a 0 response for an item that was not applicable.

Table 3: SIR II Areas of Evaluation and Number of Items

\begin{tabular}{|l|c|}
\hline \multicolumn{1}{|c|}{ Area } & Items \\
\hline Course Organization and Planning & 5 \\
\hline Communication & 5 \\
\hline Faculty/Student Interaction & 5 \\
\hline Assignments, Exams nd Grading & 6 \\
\hline Supplementary Instructional Methods & 7 \\
\hline Course Outcomes & 5 \\
\hline Student Effort and Involvement & 3 \\
\hline Course Difficulty, Work Load, and Pace & 3 \\
\hline Overall Evaluation & 1 \\
\hline Total Items & 40 \\
\hline
\end{tabular}

In an analysis of the total student course evaluations, students' overall responses supported the null hypothesis and showed that the different modes of delivery had no significant influence on the cumulative learning outcomes (Table 4). While there was variation in several areas, the study demonstrated that the instructional format did not significantly alter the effectiveness of the course.

Table 4: Statistics of SIR II by Modality

\begin{tabular}{|l|c|c|c|c|}
\hline \multicolumn{1}{|c|}{ Section } & N & Mean & Median & Std \\
\hline Online & 40 & 4.03 & 4.22 & 0.648 \\
\hline Face-to-Face & 40 & 4.07 & 4.25 & 0.725 \\
\hline
\end{tabular}

$\mathrm{T}=0.2363 \mathrm{p}=.95$ (Not significantly different)

A more meaningful insight into students' perceptions of the relative effectiveness of the two modalities can be obtained from an analysis of the individual items that were part of the general areas cited above. To allow this more in depth analysis, the mean scores for each item in each modality were compared to see the differences in 
average student perception of the course attributes evaluated in the item. Each item was then subject to a t-test to see if the differences between the formats were statistically significant. Following are tables for each area listing the items with mean scores by mode of delivery. The differences between the scores provide an insight into the relative strengths and weakness of the individual items.

\section{Course Organization}

In examining the organization and planning area, students in the face-to-face section had a more positive opinion about four of the five items. The largest differences were the explanation of course requirements and the instructor's use of class time. These could be explained by the structure of the online course where every element of the course was posted in writing on the course management system and there were no class meetings. Their views of whether the instructor had a command of the subject matter were about the same (Table 5).

Table 5: Comparative Means for Course Organization (5 very effective, 4 effective, 3 moderately effective)

\begin{tabular}{|l|c|c|c|c|c|c|c|}
\hline \multicolumn{1}{|c|}{ Item } & $\begin{array}{c}\text { Online } \\
\text { Mean }\end{array}$ & Std & $\begin{array}{c}\text { Face } \\
\text { to Face } \\
\text { Mean }\end{array}$ & Std & Mean Dif & t -test p .95 & Significant \\
\hline Instructor's explanation of course requirements & 4.60 & 0.58 & 4.38 & 0.85 & 0.22 & 1.075 & No \\
\hline Instructor's preparation for each class period & 4.28 & 1.14 & 4.38 & 0.75 & 0.10 & 0.372 & No \\
\hline Instructor's command of subject matter & 4.72 & 0.54 & 4.73 & 0.45 & 0.01 & 0.072 & No \\
\hline Instructor's use of class time & 2.96 & 2.30 & 3.54 & 1.17 & 0.58 & 1.142 & No \\
\hline Instructor's way of summarizing points & 4.32 & 1.07 & 4.35 & 0.80 & 0.03 & 0.114 & No \\
\hline
\end{tabular}

Comparison between the sections in the area of Communication showed that the face-to-face class may have been marginally more effective, but none of the results were statistically significant. Students evaluated each course as offering clear presentations, demonstrating solid command of the language and effectively using illustrations and examples. Students rated the instructor of the face-to face course as having more enthusiasm for the course material, which was to be expected given the frequent interpersonal contact between students and the professor. Students also found that the face-to-face course was better in presenting challenging questions, although neither course was given particularly high evaluations in this area (Table 6).

Table 6: Comparative Means for Course Communication (5 very effective, 4 effective, 3 moderately effective)

\begin{tabular}{|l|c|c|c|c|c|c|c|}
\hline \multicolumn{1}{|c|}{ Item } & Online Mean & Std & $\begin{array}{c}\text { Face to Face } \\
\text { Mean }\end{array}$ & Std & $\begin{array}{c}\text { Mean } \\
\text { Dif }\end{array}$ & t -test p .95 & Significant \\
\hline Clear presentations & 4.40 & 0.707 & 4.50 & 0.648 & 0.10 & 0.527 & No \\
\hline Command of spoken English & 4.84 & 0.374 & 4.92 & 0.272 & 0.08 & 0.876 & No \\
\hline $\begin{array}{l}\text { Use of examples or } \\
\text { illustrations }\end{array}$ & 4.52 & 0.653 & 4.50 & 0.648 & 0.02 & 0.072 & No \\
\hline Challenging questions & 2.96 & 2.30 & 3.54 & 1.174 & 0.58 & 0.110 & No \\
\hline $\begin{array}{l}\text { Enthusiasm for course } \\
\text { material }\end{array}$ & 4.40 & 1.041 & 4.77 & 0.430 & 0.37 & 1.671 & No \\
\hline
\end{tabular}

\section{Faculty/Student Interaction}

In their responses to the area of Faculty/Student Interaction, the face-to-face students had a much more positive experience in their relationship to the instructor. This, most likely, reflected the nature of the face-to-face format compared to the online format. The personal contact with the instructor was an important element that was lacking in the online mode. The largest differences were in the instructor's responsiveness and concern. The overall responses in this area were, again, understandable in view of the fact that there was a weekly personal interaction between the face-to-face instructor and the students. In the online class, while there was work due weekly, every 
student did not necessarily have personal contact with the instructor. This is one of the major differences between the two modalities (Table 7).

Table 7: Comparative Means for Faculty/Student Interaction (5 very effective, 4 effective, 3 moderately effective)

\begin{tabular}{|l|c|c|c|c|c|c|c|}
\hline \multicolumn{1}{|c|}{ Item } & $\begin{array}{c}\text { Online } \\
\text { Mean }\end{array}$ & Std & $\begin{array}{c}\text { Face to Face } \\
\text { Mean }\end{array}$ & Std & Mean Dif & t -test p .95 & Significant \\
\hline Instructor's helpfulness and responsiveness & 4.68 & 0.59 & 4.92 & 0.27 & 0.24 & 1.880 & No \\
\hline Instructor's respect for students & 4.60 & 1.04 & 4.96 & 0.20 & 0.36 & 1.732 & No \\
\hline Instructor's concern for student progress & 4.44 & 1.12 & 5.00 & 0.89 & 0.56 & 1.981 & No \\
\hline Availability of extra help & 4.08 & 1.85 & 4.65 & .63 & 0.57 & 1.487 & No \\
\hline Instructor's willingness to listen to students & 4.32 & 1.41 & 4.81 & 0.49 & 0.49 & 1.675 & No \\
\hline
\end{tabular}

\section{Assignments, Exams and Grading}

In the assignment area students in the online section were more impressed with the textbook than were the students in the face-to-face class. They also felt more strongly that the assignments were helpful in the course learning process and that the exams were more closely related to the course work than did the face-to-face students. The online students felt more positive about the grading information they received and the clarity of the exam questions but the differences were not large. However, the online students' more positive opinion about the helpfulness of assignments was statistically significant. This difference was probably due to the structure of the online format.

The nature of online instruction requires a more structured course, so that the responses received were expected. The fact that the face-to-face class had a more positive response to the item about comments on assignments and exams reflects the advantage of weekly personal contact with the instructor. Many of the online exams had an automatic feedback included in the course learning program, but this did not substitute for the personal response of the fully engaged face-to-face instructor (Table 8).

Table 8: Comparative Means for Assignments, Exams and Grading (5 very effective, 4 effective, 3 moderately effective)

\begin{tabular}{|l|c|c|c|c|c|c|c|}
\hline \multicolumn{1}{|c|}{ Item } & $\begin{array}{c}\text { Online } \\
\text { Mean }\end{array}$ & Std & $\begin{array}{c}\text { Face to Face } \\
\text { Mean }\end{array}$ & $\begin{array}{c}\text { Std } \\
\text { Information on grading }\end{array}$ & $\begin{array}{c}\text { Mean } \\
\text { Dif }\end{array}$ & $\mathbf{t}$-test p .95 & Significant \\
\hline Clarity of exam questions & 4.48 & 1.12 & 4.38 & 0.94 & .02 & .0692 & No \\
\hline $\begin{array}{l}\text { Exam covers important aspects of } \\
\text { course }\end{array}$ & 4.44 & 1.08 & 4.35 & 0.80 & .09 & .3391 & No \\
\hline Comments on assignments and exams & 3.76 & 1.86 & 4.54 & 0.71 & .73 & 1.993 & No \\
\hline Quality of textbook & 4.64 & 0.49 & 4.00 & 1.39 & .64 & 1.644 & No \\
\hline $\begin{array}{l}\text { Helpfulness of assignments re course } \\
\text { material }\end{array}$ & 4.68 & 0.48 & 4.23 & 0.99 & .45 & 2.052 & Yes \\
\hline
\end{tabular}

\section{Supplementary Instructional Methods}

By the very nature of the two modes of delivery, there were different methodologies used, even though the content was the same. However, there was still no significant difference in the student evaluations of the methods listed, except in two cases where there were statistically significant differences (Table 9). These were team projects that were used in the face-to-face class, but not in the online section. The other was the use of computers which was the heart of the online mode, but not used in the face-to-face class. The lesson to be learned from this is that the online mode of delivery should develop online team projects and the face-to-face mode should consider using online applications in the delivery of the content. 
Table 9: Comparative Means for Supplementary Instructional Methods

(5 very effective, 4 effective, 3 moderately effective, 2-0 ineffective or not used)

\begin{tabular}{|l|c|c|c|c|c|c|c|}
\hline \multicolumn{1}{|c|}{ Item } & Online mean & Std & Face to Face Mean & Std & Mean Dif & t-test p .95 & Significant \\
\hline Problems for Groups & 3.52 & 2.064 & 3.19 & 1.721 & 0.33 & 0.621 & No \\
\hline Term Paper & 4.52 & 0.586 & 4.23 & 0.765 & 0.29 & 1.515 & No \\
\hline Labatory Exercises & 3.08 & 2.197 & 2.08 & 2.938 & 1.00 & 1.372 & No \\
\hline Assigned Team Projects & 2.08 & 2.414 & 4.12 & 1.633 & 2.04 & 3.547 & Yes \\
\hline Case Studies & 4.12 & 1.364 & 4.31 & 1.289 & 0.19 & 0.511 & No \\
\hline Course Journals & 2.52 & 2.33 & 2.62 & 2.639 & 0.10 & 0.143 & No \\
\hline Computers as aid & 4.56 & 0.507 & 1.85 & 2.541 & 2.71 & 5.231 & Yes \\
\hline
\end{tabular}

\section{Course Outcomes}

The students' opinions of how their particular modality helped them learn was the most relevant and useful information gathered from the student evaluations. Even though the results on the final common examination were virtually the same, the face-to-face students had a more positive response to the question of whether their learning had increased. Perhaps the most interesting response was that the online students were a little less positive than the face-to-face students about being actively involved in their learning. This was a surprise since the conventional wisdom is that the structure of an online course forces students to be more actively involved in their learning. This was the area of greatest difference between the two groups, though it is not statistically significant. The online students were more favorable in their responses to the other three items. They were more positive on the question of whether they made progress toward course objectives. They were also more positive about the course helping them to think independently and having increased their interest in the subject (Table 10).

Table 10: Comparative Means for Course Outcomes

(5 much more than most, 4 more than most, 3 about the same)

\begin{tabular}{|l|c|c|c|c|c|c|c|}
\hline \multicolumn{1}{|c|}{ Item } & $\begin{array}{c}\text { Online } \\
\text { Mean }\end{array}$ & Std & $\begin{array}{c}\text { Face to Face } \\
\text { Mean }\end{array}$ & Std & $\begin{array}{c}\text { Mean } \\
\text { Dif }\end{array}$ & t -test p .95 & Significant \\
\hline Learning increased in course & 3.92 & 1.08 & 4.04 & 0.77 & 0.12 & .4583 & No \\
\hline Made progress toward course objectives & 4.19 & .75 & 4.08 & 1.15 & 0.11 & .9962 & No \\
\hline Interest in subject increased & 4.08 & 1.15 & 3.96 & 0.96 & 0.12 & .5402 & No \\
\hline $\begin{array}{l}\text { Helped ability to think independently re } \\
\text { subject }\end{array}$ & 4.16 & 1.11 & 3.96 & .92 & 0.20 & .7045 & No \\
\hline Actively involved student in learning & 3.52 & 1.74 & 4.00 & 0.80 & 0.49 & 1.2769 & No \\
\hline
\end{tabular}

\section{Student Effort}

The face-to-face students, on average, thought they put more effort into the course than did the online students (Table 11). In an article on the relationship between student effort and learning, as reflected in the SIR II, it was found that student effort was positively related to their perception of their learning (Carroll and O'Donnell, 2008). This item of student effort could be an argument for the superior effectiveness of the face-to-face modality in this study, even though the outcomes reflected in the final examination were similar. Online students expressed that they found the course more challenging, but none of the results in the area of student effort were statistically significant.

Table 11: Comparative Means for Student Effort

(5 much more than most, 4 more than most, 3 about the same)

\begin{tabular}{|l|c|c|c|c|c|c|c|}
\hline \multicolumn{1}{|c|}{ Item } & $\begin{array}{c}\text { Online } \\
\text { Mean }\end{array}$ & Std & $\begin{array}{c}\text { Face to Face } \\
\text { Mean }\end{array}$ & Std & $\begin{array}{c}\text { Mean } \\
\text { Dif }\end{array}$ & t-test p .95 & Significant \\
\hline Studied and put effort in course & 4.12 & 1.166 & 4.27 & 0.778 & .15 & .5424 & No \\
\hline Prepared for each class & 3.68 & 1.600 & 3.85 & 0.784 & .17 & .4848 & No \\
\hline Challenged by course & 3.88 & 1.130 & 3.81 & 1.059 & .07 & .2284 & No \\
\hline
\end{tabular}




\section{Course Difficulty}

The face-to-face students found their course work and work load somewhat more difficult than did the online students. They also found the pace of the course more difficult, even though they had twice as much time to complete it. However, the differences were, once again, not statistically significant (Table 12).

Table12: Comparative Means for Course Difficulty and Work Load (5 very difficult, 4 somewhat difficult, 3 about right)

\begin{tabular}{|l|c|c|c|c|c|c|c|}
\hline \multicolumn{1}{|c|}{ Item } & $\begin{array}{c}\text { Online } \\
\text { Mean }\end{array}$ & Std & $\begin{array}{c}\text { Face to Face } \\
\text { Mean }\end{array}$ & Std & $\begin{array}{c}\text { Mean } \\
\text { Dif }\end{array}$ & t-test p .95 & Significant \\
\hline For my preparation and ability & 2.96 & 1.098 & 3.46 & 0.761 & .50 & 1.896 & No \\
\hline Work load equal to other courses & 3.28 & 1.137 & 3.92 & 0.845 & .64 & .6451 & No \\
\hline Pace of course & 3.08 & .628 & 3.60 & 1.291 & .52 & .2284 & No \\
\hline
\end{tabular}

\section{Overall Evaluation}

In the Overall Evaluation, as with the area on Faculty/Student Interaction, there was a significant difference between the face-to-face student response and the online student response (Table 13). The face-to-face students had a significantly better opinion of the effectiveness of their instruction than did the online students. As in the Faculty/Student Interaction area, this could have reflected the nature of the face-to-face format compared to the online format. The personal contact with the instructor may have enhanced the learning experience in a way that was different from the online modality.

Table 13: Comparative Means for Overall Evaluation

(5 very effective, 4 effective, 3 moderately effective)

\begin{tabular}{|c|c|c|c|c|c|c|c|}
\hline Item & Online Mean & Std & Face to Face Mean & Std & Mean Dif & t -test p .95 & Significant \\
\hline Quality of instruction & 3.60 & 1.291 & 4.31 & 0.838 & -.71 & 2.339 & Yes \\
\hline
\end{tabular}

\section{LIMITATIONS OF THE STUDY}

The limitations of the study include the fact that a different instructor was involved in each section. The syllabi also had variations that could have biased the outcome. These would include the mid-term examination, only for the face-to-face section, and the weekly quizzes, only for the online section. The study was also limited in that the final examination was the only objective outcome measure and did not evaluate the effectiveness of other objective outcomes of the course. Other outcomes were considered, but only as student self-reported data. However, these results add to the literature regarding online and face-to-face teaching effectiveness and provided useful insights into the question raised by the study.

\section{CONCLUSION}

The results of this research do not support the position that an online instructional modality is more effective than a face-to-face one. This conclusion was based on the fact that the results of the final examinations of the two sections were virtually the same with no statistically significant difference between them. In addition, the results of the SIR II student evaluations conflicted with the hypothesis that online instruction was more effective. Although there were very few significant differences between the student responses for most of the items, the faceto-face students reported a higher degree of effectiveness in most areas. In fact, the face-to-face students had a higher mean response in 26 of the 40 items. These results do not preclude the possibility that a different measure of effectiveness might produce a different result. However, the study did support the finding in much of the literature that each modality can contribute to an effective educational experience in a different way. 


\section{AUTHOR INFORMATION}

Norman E. Carroll, PhD is University Professor of Business and Economics in the Brennan School of Business at Dominican University. He is also Provost Emeritus of Dominican University. His research interest is in the area of organizational structure and change. He is currently focused on studying the entrepreneurial dimension in organizational effectiveness.

Molly Burke, $\mathrm{PhD}$ is Associate Professor of Management in the Brennan School of Business at Dominican University. She is also Dean Emeritus of the Brennan School. Her research interest is in the role of leadership in organizations. She is currently involved in the study of social entrepreneurship.

\section{REFERENCES}

1. Alonso Dias, L., and Blazquez Entonado, F. (2009). Are the Functions of Teachers in e-Learning and Faceto-FaceLearning Environments Really Different? Educational Technology \& Society. 12(4), 331-343

2. Brownstein, B., Brownstein, D., Gerlowski, D.(2008).Web-Based vs. Face-to-Face MBA Classes: A Comparative Assessment Study, Journal of College Teaching \& Learning 5 (11) ,41-48.

3. Carle, A. C. (2009). Evaluating College Students' Evaluations of a Professor's Teaching Effectiveness across Time and Instruction Mode (Online vs. Face-to-Face) Using a Multilevel Growth Modeling Approach. Computers \& Education. 53(2), 429-435

4. Carroll, N. and O’Donnell, M. (2010) Some Critical Factors in Student Learning. International Journal of Education Research. Vol. 5 No. 1 p 59-69

5. Chen, C. and Jones, K. (2007, January). Blended Learning vs. Traditional Classroom Settings: Assessing Effectiveness and Student Perceptions in an MBA Accounting Course [Electronic version]. The Journal of Educators Online. Vol. 4. No. 1.

6. Cragg, C. E., Dunning, J., \& Ellis, J. (2008). Teacher and Student Behaviors in Face-to-Face and Online Courses: Dealing with Complex Concepts. Journal of Distance Education. 22(3), 115-128.

7. Gibson J. (2008). A Comparison of Student Outcomes and Student Satisfaction in Three MBA Human Resource Management Classes Based on Traditional vs. Online Learning, Journal of College Teaching \& Learning, 5 (8), 1-10

8. Haavind, S. (2000, Fall). Why Don't Face-to-Face Teaching Strategies Work In the Virtual Classroom? [Electronic version]. The Concord Consortium. Vol. 4 No. 3.

9. Kirtman, L. (2009). Online versus In-Class Courses: An Examination of Differences in Learning Outcomes. Issues in Teacher Education. 18(2), 103-116

10. Kishore, M., Tabrizi, M. H. N., Ozan, E., Aziz, S., and Wuensch, K. L. (2009). Correlates of Student Preference for Online Instruction over Face-to-Face Instruction. E-Learning. 6(4), 400-415

11. Larson, D. K., and Sung, C.-H. (2009). Comparing Student Performance: Online versus Blended versus Face-to-Face. Journal of Asynchronous Learning Networks. 13(1), 31-42.

12. McGovern, G. (2004, June). Teaching Online vs, Face-to-Face. [Electronic version]. CLENExchange, Newsletter of American Library Association Continuing Education Network \& Exchange Roundtable. Vol. 20 No. 4.

13. Singh D.,\& Stoloff, D. (2007). Effectiveness of Online Instruction: Perceptions of Pre-Service Teachers. International Journal of Technology, Knowledge \& Society v2 n6 p121-124

14. Sipes, K. A. and Ricciardi, V, (2006) Online vs. Face to Face: Is There a Difference in How Accounting and Finance Students Learn in an Online vs. Face-to-Face Setting. SSRN. Retrieved September 9, 2010 from http://ssrn.com/abstract $=894223$

15. Sugar, W., Martindale, T., \& Crawley, F. E. (2007). One Professor's Face-to-Face Teaching Strategies while Becoming an Online Instructor. Quarterly Review of Distance Education. 8(4), 365-385.

16. Teaching College Courses Online vs Face-to-Face, (2001, April 1 ) The Journal Digital Edition, Retrieved September 26, 2010 from http://thejournal.com/articles/2001/04/01/teaching-college-courses-online-vsfacetoface.aspx.

17. Turball, J. (2002). From Face-to-Face Teaching to Online Distance Education Classes: Some Challenges and Surprises. ASCILITE 2002 conference proceedings. Retrieved September 9, 2010 from: http://www.ascilite.org.au/conferences/auckland02/proceedings/papers/127.pdf. 
18. Tutty, J. I., \& Klein, J. D. (2008). Computer-Mediated Instruction: A Comparison of Online and Face-toFace Collaboration. Educational Technology Research and Development. 56(2), 101-124.

19. U.S. Department of Education Office of Planning and Policy Development (n.d.) . Evaluation Report. Retrieved June 26, 2009 from, http://www.ed.gov/about/offices/list/opepd/ppss/reports.html\#edtech.

20. Wong,L. and Tatnall, A. (2009).The Need to Balance the Blend: Online versus Face-to-Face Teaching in an Introductory Accounting Subject [Electronic version]. Issues in Informing Science and Information Technology, Vol.6. 
APPENDIX 1

\section{STUDENT INSTRUCTIONAL REPORT (SIR II)}

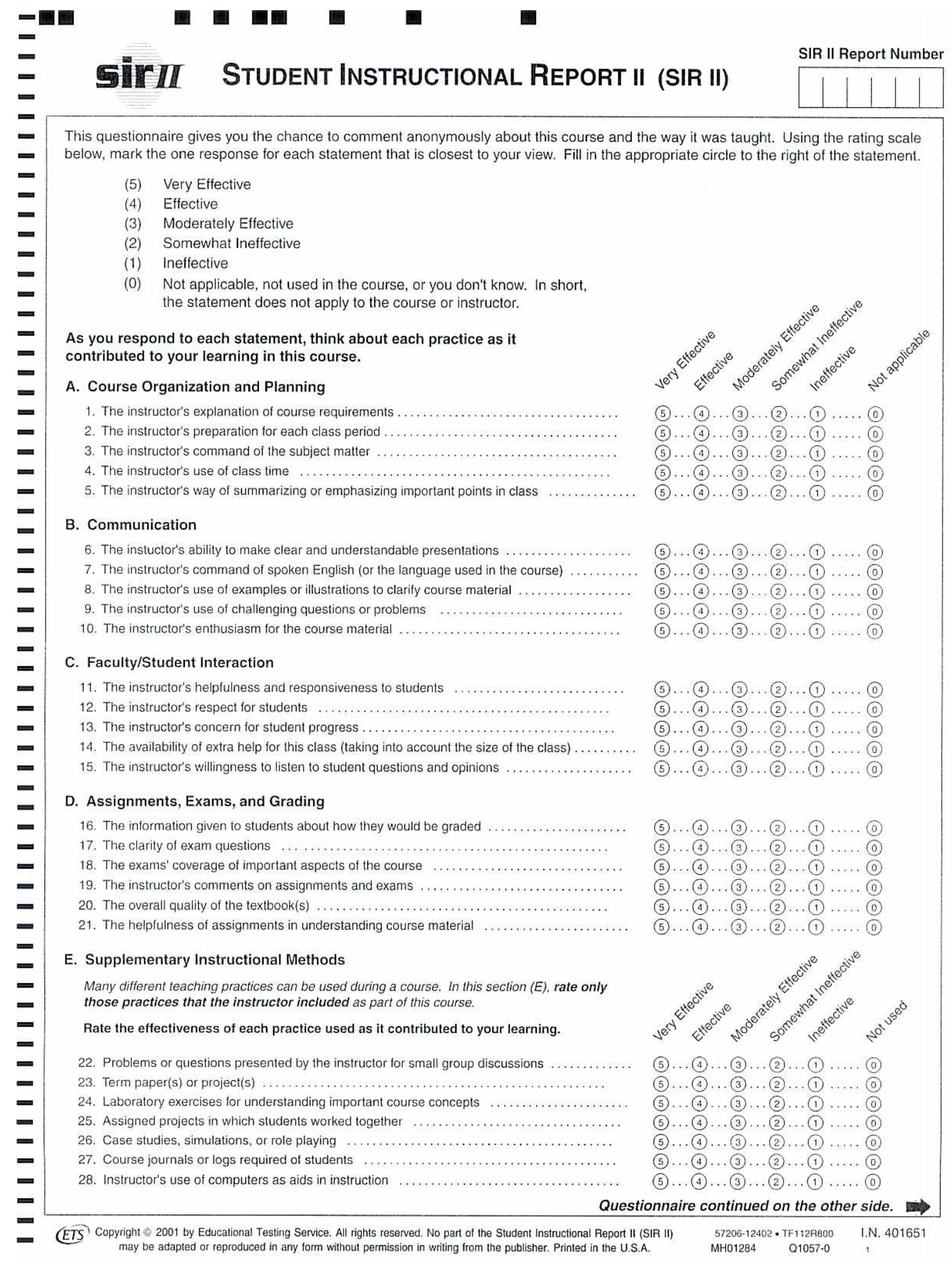




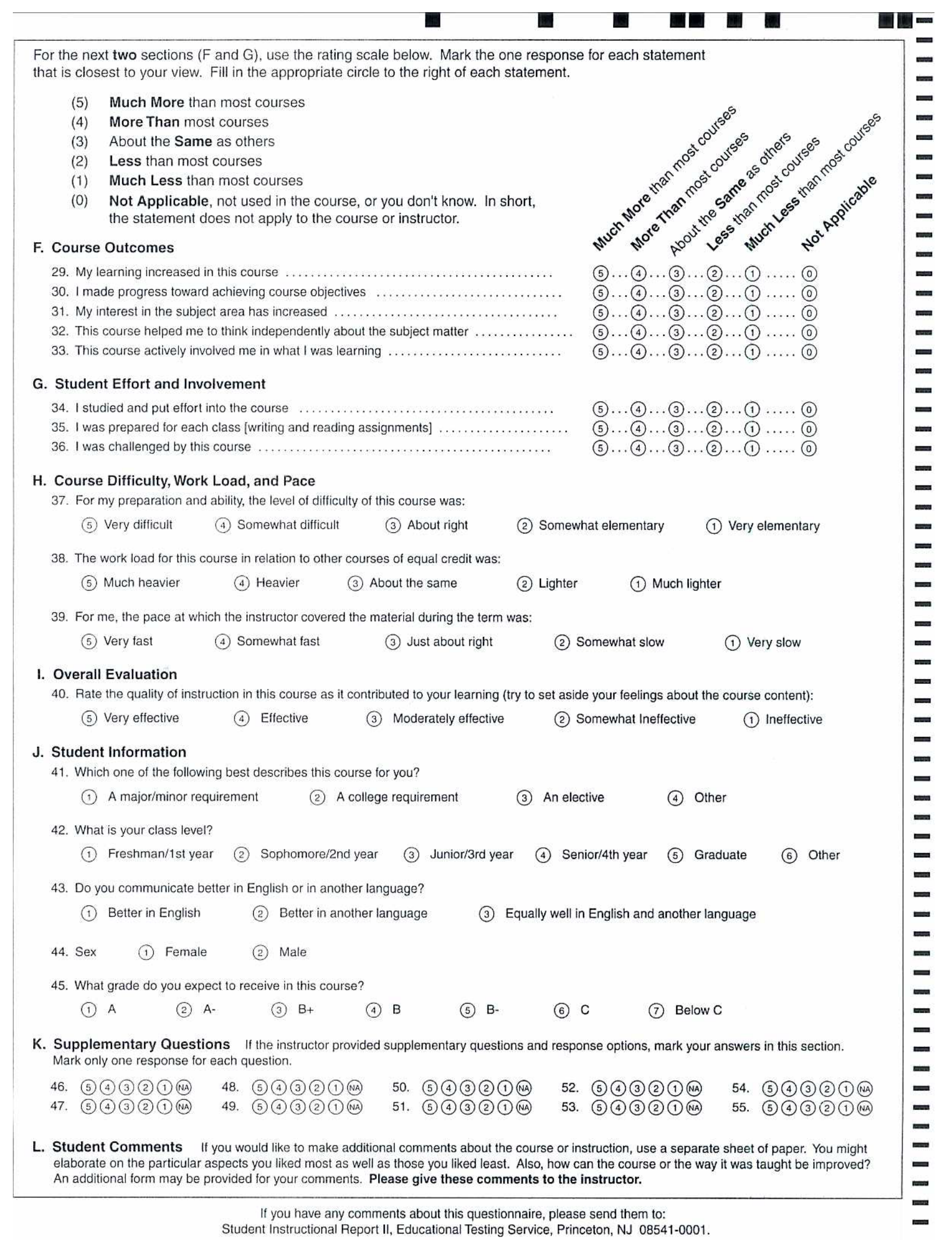

